\title{
Rent Control and Virtual Prices: A Case Study for Interwar Belgium
}

\section{Leon Bettendorf; Erik Buyst}

The Journal of Economic History, Vol. 57, No. 3. (Sep., 1997), pp. 654-673.

Stable URL:

http://links.jstor.org/sici?sici=0022-0507\%28199709\%2957\%3A3\%3C654\%3ARCAVPA\%3E2.0.CO\%3B2-N

The Journal of Economic History is currently published by Economic History Association.

Your use of the JSTOR archive indicates your acceptance of JSTOR's Terms and Conditions of Use, available at

http://www.jstor.org/about/terms.html. JSTOR's Terms and Conditions of Use provides, in part, that unless you have obtained prior permission, you may not download an entire issue of a journal or multiple copies of articles, and you may use content in the JSTOR archive only for your personal, non-commercial use.

Please contact the publisher regarding any further use of this work. Publisher contact information may be obtained at http://www.jstor.org/journals/eha.html.

Each copy of any part of a JSTOR transmission must contain the same copyright notice that appears on the screen or printed page of such transmission.

The JSTOR Archive is a trusted digital repository providing for long-term preservation and access to leading academic journals and scholarly literature from around the world. The Archive is supported by libraries, scholarly societies, publishers, and foundations. It is an initiative of JSTOR, a not-for-profit organization with a mission to help the scholarly community take advantage of advances in technology. For more information regarding JSTOR, please contact support@ jstor.org. 


\title{
Rent Control and Virtual Prices: A Case Study for Interwar Belgium
}

\author{
LEON BETTENDORF AND ERIK BUYST
}

\begin{abstract}
After World War I rent control became a cornerstone of housing policy in many European countries, resulting in quantity constraints on the demand for housing. The theory on complete demand systems provides a framework for analyzing the effects of these policies on consumption. As a test case, a demand model is estimated to calculate virtual rent prices for interwar Belgium. The results are well in line with historical evidence, providing insight into the extent of rationing. Simulations with the demand model show that the severe rent restrictions especially favored expenditures on food.
\end{abstract}

Tr thee $\mathrm{n}$ the nineteenth century, housing markets in western Europe were usually free of government control. World War I brutally disrupted the fragile equilibrium between the supply and demand of housing. Where the war was fought many houses were destroyed. Elsewhere, shortages of building materials, high mortgage rates, and uncertainty caused a sharp reduction in residential construction. The resulting housing shortage threatened to send rents sky high, so rent control became a cornerstone of housing policy, even in neutral countries. ${ }^{1}$ Contrary to original expectations, rent control proved to be more than a temporary wartime measure. Postwar inflation and unanticipated difficulties in resolving the housing shortage delayed the removal of rent restrictions considerably. In Britain, the first steps towards deregulation of rents were taken in 1923, but decontrol only gained momentum in the 1930s; on the eve of World War II about 30 percent of all dwellings were still subject to rent restrictions. ${ }^{2}$ In France rent control remained in effect until $1937 .{ }^{3}$ In many respects the interwar period can be considered the heyday of rent freeze. ${ }^{4}$

The impact of rent control on the housing market is a much debated issue in economic research. Recently, it again has become a subject of controversy. ${ }^{5}$ It is striking that in historical studies little use has been made of

The Journal of Economic History, Vol. 57, No. 3 (Sept. 1997). The Economic History Association. All rights reserved. ISSN 0022-0507).

Leon Bettendorf, Central Planning Bureau, P.B. 80510, 2508 GM Den Haag, The Netherlands, email: 1jhb@cpb.nl; Erik Buyst, Center for Economic Studies, University of Leuven, Naamsestraat 69, B-3000 Leuven, Belgium, email: erik.buyst@econ.kuleuven.ac.be.

Thanks are due to Anton B. Barten for many stimulating suggestions. The comments of Joel Mokyr, Guido Pepermans, Antoon Soete, Peter Solar, Michelangelo van Meerten, and two anonymous referees are highly appreciated. Bettendorf acknowledges Tinbergen Institute Rotterdam.

${ }^{1}$ In Sweden and Switzerland, for instance, the housing shortage during World War I was severe enough to impose rent controls (Strömberg, "Sweden," p. 21; and Kurz, "Arbeiter," p. 288).

${ }^{2}$ Richardson and Aldcroft, Building, pp. 189-90.

${ }^{3}$ Lescure, Immobilier, p. 140.

${ }^{4}$ For an overview, see Pooley, Housing Strategies.

5For an overview, see Arnott, “Time," pp. 99-120. 
modern microeconomics in general and of so-called complete demand systems in particular to settle the debate. Using rents in interwar Belgium as a test case, we investigate in this article the effects of rent restrictions by calculating "virtual rents" on the basis of estimated demand models (what would the level of rents have been without control given the observed quantities?). After a short overview of rent control in interwar Belgium, we briefly discuss demand theories, without and with rationing. It is shown that both theories can be linked using the concept of virtual prices. The virtual price is the price the consumer would be willing to pay voluntarily for the actual quantity supplied. A demand model is estimated using Belgian interwar and post-World War II data. This provides the necessary information to calculate virtual rent prices, the size and evolution of which give a more precise insight into the extent of rationing. Finally, the demand model is simulated with alternative patterns for the controlled rent prices to analyze further the effects of rationing on consumption.

\section{RENT CONTROL IN INTERWAR BELGIUM}

Belgium is for several reasons an interesting case of rent control. During World War I about 84,000 houses, more than 5 percent of the housing stock, were completely or partially destroyed. At the same time, new construction came to an almost complete standstill. ${ }^{6}$ The resulting housing shortage became acute after the armistice as the nearly 600,000 Belgian refugees in France, Great Britain, and the Netherlands returned home. ${ }^{7}$ Surveys of housing conditions in the 1920 s present a compelling picture of overcrowding. In many cases several households had to share a single-family dwelling. 8 Figure 1 illustrates the deterioration of housing conditions during and immediately after World War I.

In order to keep the situation under control, the Belgian Parliament decided in August 1919 to extend leases and to limit rents to a maximum of 30 percent above the level reached in August 1914. A year later, in order to overcome the resistance of refractory owners, local authorities were authorized to claim unoccupied houses. As a sop to the owners, the limit for rent increases was in some cases raised to 50 percent of the August 1914 level. ${ }^{9}$ Nevertheless, landlords continued to oppose rent control fiercely, and not surprisingly since consumer prices (rents excluded) had risen more than 350 percent over the same period. ${ }^{10}$

Why were rents in Belgium restricted to such a low level? Belgian offi-

\footnotetext{
${ }^{6}$ Buyst, Economic History, pp. 188, 222.

${ }^{7}$ Schepens, "België," p. 27.

${ }^{8}$ Gobyn, "Woningnood," p. 185; and Baudhuin, Histoire économique, vol. 1, p. 103.

${ }^{9}$ For a detailed overview of Belgian rent legislation, see Henau, "Belgische huishuren," pp. 10-17.

${ }^{10}$ Calculated from Banque Nationale de Belgique, Statistiques économiques, p. 40.
} 


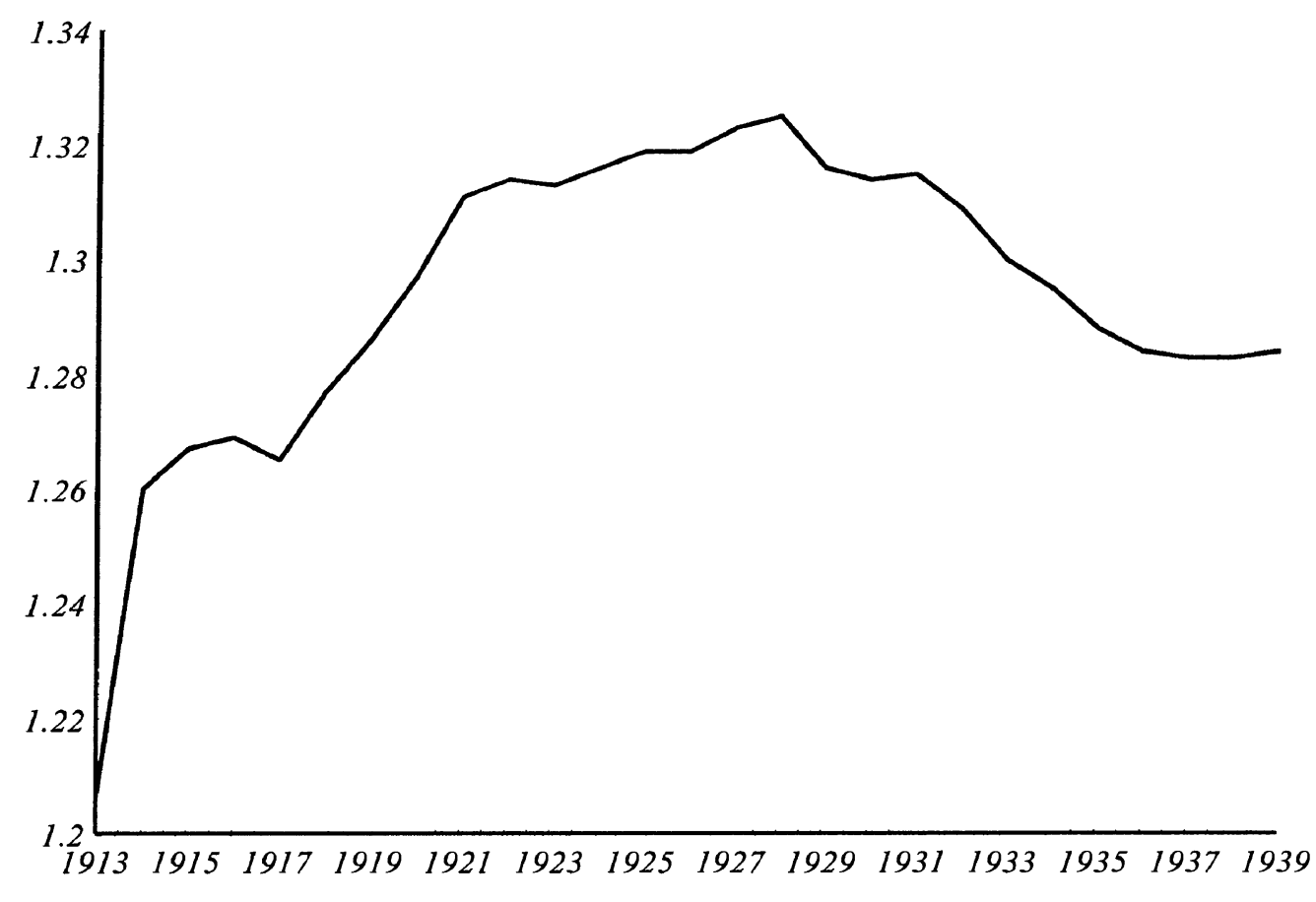

FIGURE 1

NUMBER OF FAMILIES PER HOUSE, BELGIUM, 1913-1939

Source: Data were calculated from Buyst, Economic History, pp. 260-61, 263.

cials firmly believed that postwar inflation was essentially a temporary phenomenon. The government expected that prices would soon start to decline to prewar levels. ${ }^{11}$ From that perspective permitting steep rent increases would only have hampered the success of deflationary policies. Of course, the Belgian government's aim to reduce the general price level by a factor of 4.5 was unrealistic. Moreover, as the government continued to pursue lax budgetary and monetary policies in the early 1920s, it soon thwarted its own drive towards deflation. ${ }^{12}$ From the middle of 1922 , consumer prices (rents excluded) started to rise again, forcing Parliament to permit some limited rent increases (see Table 1).

The severe budgetary and monetary crisis of 1926 caused inflation to accelerate dramatically. As a result, the discrepancy between frozen rents and other consumer prices reached unprecedented heights. In October 1926 consumer prices (rents excluded) had risen 600 percent since August 1914, while rent increases were limited to a maximum of 125 percent. In such circumstances, rent control, although originally designed to protect tenants,

\footnotetext{
${ }^{11}$ Van der Wee and Tavernier, Banque Nationale, pp. 33-36.

${ }^{12}$ For more details, see Buyst et al., "National Accounts," pp. 70-72; and Cassiers, Croissance, pp. 127-40; Hogg, Structural Rigidities, pp. 13-21; and Mommen, Belgian Economy, pp. 1-10.
} 
TABLE 1:

RENT RESTRICTIONS IN INTERWAR BELGIUM

(percentage increase on August 1914)

\begin{tabular}{lcccccc}
\hline \hline & \multicolumn{5}{c}{$\begin{array}{c}\text { Permitted Rent Increase } \\
\text { (percentage) }\end{array}$} \\
\cline { 2 - 6 } $\begin{array}{l}\text { Date of Act or } \\
\text { Royal Decree }\end{array}$ & $\begin{array}{c}\text { All Classes } \\
\text { of Dwellings }\end{array}$ & $\begin{array}{c}\text { Class A } \\
\text { Dwellings }\end{array}$ & $\begin{array}{c}\text { Class B } \\
\text { Dwellings }\end{array}$ & $\begin{array}{c}\text { Class C } \\
\text { Dwellings }\end{array}$ & $\begin{array}{c}\text { Class D } \\
\text { Dwellings }\end{array}$ & $\begin{array}{c}\text { Date of } \\
\text { Application }\end{array}$ \\
\hline 25 August 1919 & 30 & & & & & immediately \\
14 August 1920 & 50 & & & & & immediately \\
20 February 1923 & 100 & & & & & immediately \\
immediately \\
27 December 1924 & 125 & free & 225 & 175 & 150 & immediately \\
28 December 1926 & & & free & 225 & 200 & 1928 \\
& & & & free & 225 & 1929 \\
31 December 1929 & & & & & 600 & immediately \\
11 March 1938 & & & & & 700 & immediately \\
\hline
\end{tabular}

Notes: Class A dwellings are very expensive; Class B dwellings are expensive; Class C dwellings are medium-sized; and Class D dwellings are low-rent dwellings. Table 1 presents only the broad outline of rent control in Belgium. For a complete overview, see Buyst, Inkomen, pp. 10-12.

Sources: Belgisch Staatsblad [Belgian Law Gazette], various issues.

became more and more a financial punishment for landlords. The monetary crises of 1926 ended with the stabilization of the Belgian franc at one-seventh of its 1914 gold parity. This steep devaluation of the franc dashed any hope of returning to the prewar price level. At the same time, the conviction grew-based on statistics that highly exaggerated actual building activity - that the postwar housing shortage had largely been remedied. ${ }^{13}$ The government decided that time had come for progressive decontrol of rents.

The Act of 28 December 1926 liberalized rents to a considerable degree. Four categories of dwellings (A, B, C, and D) were distinguished according to rateable value. Rents of very expensive dwellings (class $A$ ) became free in the course of 1927. In the case of expensive dwellings (class B) rents could be raised by up to 225 percent in 1927 and were to be decontrolled completely in 1928. The maximum rent of medium-sized dwellings (class C) was set at 175 percent in 1927 and 225 percent in 1928, with a free market from 1929. For low-rent dwellings (class D) limited rent increases were permitted in the 1927 to 1929 period (see Table 1). ${ }^{14}$ With effect from 1930 , all compulsory extension of leases and rent restrictions would end-at least that was the intention. It turned out that a complete liberalization of rents was not feasible. In 1929 it was decided to continue rent control for some subcategories of class D dwellings. In exchange, a steep rent increase of 600 percent vis-à-vis August 1914 was allowed, which in 1938 was finally raised to 700 percent.

\footnotetext{
${ }^{13}$ Buyst, Economic History, pp. 53-54, 69-70.

${ }^{14}$ Table 1 presents only the broad outline of rent control in Belgium. For a complete overview, see Buyst, "Inkomen," pp. 10-12.
} 
This short overview clearly indicates that especially in the 1920 s the Belgian government intervened extensively in the housing market. To what extent were legal regulations obeyed? This is an important issue as approximately 65 percent of Belgian families were tenants in the interwar period. ${ }^{15}$ Research suggests that in general rent control was well observed until 1924. Thereafter the discrepancy between the frozen rents and consumer prices apparently became too wide. The stepwise increases prescribed by the Rent Act of 1926 were sometimes ignored: from 1927 to 1929 rents of low-rent dwellings occasionally rose considerably faster than permitted. ${ }^{16}$ Anne Henau's rent index takes this problem into account as it is based on records of landlords that indicate the actual rent paid (Figure 2) ${ }^{17}$ In the 1930s the maximum limit of rent increases was high enough not to disturb the normal functioning of the market for low-rent dwellings. ${ }^{18}$

Building activity responded swiftly to the decontrol of rents. The number of new houses constructed jumped from 27,000 per year between 1923 and 1927 to 35,000 per annum during the period 1929 to 1933 . Information from land registry documents indicates that the average size of newly built houses also increased after the relaxation of rent control. ${ }^{19}$

\section{THE THEORY ON DEMAND SYSTEMS}

The theory of complete demand systems provides a consistent framework to explain the allocation of a consumer's budget over different commodities. ${ }^{20}$ The microeconomic theory of consumption is built on the assumption that the consumer selects the best bundle that he can afford, given the available financial means and the observed prices. From this framework follows that consumption of each commodity $x_{i}$ is determined by the budget $m$ and all the prices $p_{1}, p_{2}, \ldots, p_{n}$

$$
x_{i}=f_{i}(m, p) \quad i=1, \ldots, n
$$

where $n$ is the number of goods considered, $m=\sum_{i} p_{i} x_{i}$ (which is the sum of expenditures on individual goods has to equal total available means) and $p$

\footnotetext{
${ }^{15}$ Before the 1947 census (61 percent tenants) quantitative information on Belgian housing tenure is lacking. Local inquiries suggest that the share of tenants was considerably higher in the late nineteenth and early twentieth centuries (Van den Eeckhout, "Belgium," p. 197).

${ }^{16}$ Leeman, Woningmarkt, p. 70; and Henau, "Belgische huishuren," pp. 17-18.

${ }^{17}$ Henau, "Belgische huishuren," pp. 17-18; and Buyst, Inkomen, pp. 17-18, 25.

${ }^{18}$ Baudhuin, Histoire économique, vol. 1, p. 104; Leeman, Woningmarkt, p. 70; and Buyst, Inkomen, p. 18.

${ }^{19}$ For a detailed account, see Buyst, Economic History, pp. 186-207.

${ }^{20}$ Excellent overviews of demand theory are given by Deaton and Muellbauer, Economics, p. 438; Phlips, Applied Consumption, p. 331; and Thomas, Applied Demand, p. 104. Application to historical data can be found in Schokkaert and Van der Wee, "Quantitative Study," pp. 131-58; and Pepermans, "De inkomens," pp. 311-24.
} 
denotes the vector of $n$-prices ${ }^{21} \mathrm{~A}$ standard starting point is the logarithmic specification of equation 1 in differential form: ${ }^{22}$

$$
\Delta \ln x_{i}=\eta_{i} \Delta \ln m+\Sigma_{j} \varepsilon_{i j} \Delta \ln p_{j}
$$

where $\Delta l n$ stands for the change in the logarithm of the variable. The parameter $\eta_{i}$ is interpreted as the income elasticity of commodity $i$, and $\varepsilon_{i j}$ the elasticity of demand for good $i$ with respect to the price of $j$. From the definition of the budget share $w_{i}=p_{i} x_{i} / m$ and the budget restriction follows:

$$
\Delta \ln m=\Sigma_{j} w_{i} \Delta \ln x_{j}+\Sigma_{j} w_{j} \Delta \ln p_{j}
$$

Substituting equation 3 in equation 2 and multiplying both sides with $w_{i}$ yields the so-called Rotterdam parametrization in differential form:

$$
w_{i} \Delta \ln x_{i}=a_{i}+b_{i}\left(\Delta \ln m-\Sigma_{j} w_{j} \Delta \ln p_{j}\right)+\Sigma_{j} s_{i j} \Delta \ln p_{j} \quad i, j=1, \ldots, n
$$

with

$$
\begin{aligned}
& b_{i}+w_{i} \eta_{i} \\
& s_{i j}=w_{i}\left(\varepsilon_{i j}+\eta_{i} w_{j}\right)
\end{aligned}
$$

An intercept $a_{i}$ is included to reflect trend shifts. The next explanatory variable equals the percentage change in nominal income minus a weighted sum of price changes and can thus be interpreted as the change in real income. Coefficient $b_{i}$ therefore represents income effects, as reflected in the expression for income elasticity $\eta_{i}=b_{i} / w_{i}$. Coefficient $s_{i i}$ gives the own compensated price effect while the $s_{i j}(i \neq j)$ give cross-price effects. The term compensated here means that real income is kept constant by adjusting nominal income after price changes. ${ }^{23}$ The sign of $s_{i j}$ gives an indication of the direction of interaction between the commodities. When $s_{i j}>0$, a price increase of good $j$ results in an increased (compensated) demand for good $i$ and the two goods are said to be substitutes; when $s_{i j}<0$ the commodities are complementary. The compensated price elasticities are calculated as $s_{i j} / w_{i}$, and the uncompensated price elasticities equal $\varepsilon_{i j}=\left(s_{i j}-b_{i} w_{j}\right) / w_{i}$. Notice that the elasticities are not constant in time since they depend on the variable budget shares.

The framework from which the demand equations are derived implies four types of restrictions. With the Rotterdam specification these restrictions can easily be imposed on the estimation, yielding an advantageous decrease in the number of coefficients to be estimated. The first set of constraints

\footnotetext{
${ }^{21}$ To be more specific, equation 1 is derived from the first-order conditions of $\max _{x}\{u(x)$, subject to $\left.p^{\prime} x=m\right\}$, where $u(x)$ denotes the utility function. The demand function can be extended with other taste determining variables.

${ }^{22}$ See Barten, "Consumer Allocation," pp. 139-40; and Schokkaert and Van der Wee, "Quantitative Study," pp. 155-57.

${ }^{23}$ For infinitesimal price changes, holding real income fixed is equivalent to holding utility fixed, see Varian, "Microeconomic Analysis," p. 144.
} 
concerns the adding-up conditions $\sum_{i} a_{i}=0, \sum b_{i}=1$ and $\sum s_{i j}=0$. Thes $\epsilon$ restrictions follow from the budget constraint: changes brought about in expenditures on individual goods always have to sum up to the change in the total budget. Second, homogeneity is imposed with $\sum_{j} s_{i j}=0$. This implies the absence of money illusion: a proportional change in income and all prices does not affect the quantities consumed. Third, symmetry is expressed as $s_{i j}=s_{j i}$. The (compensated) effect of a change in $p_{j}$ on $x_{i}$ equals the (compensated) effect of a change in $p_{i}$ on $x_{j}$. The fourth is the negativity condition on the matrix S. The main implication is that $s_{i i}<0(\forall i)$ meaning that (compensated) demand decreases following an own-price increase.

When the consumer cannot allocate his budget freely but is confronted with quantity constraints, the framework has to be adjusted to incorporate rationing effects. ${ }^{24}$ Suppose for simplicity that the quantity constraint is imposed for only one good: $x_{h}=\bar{x}_{h}$ with price $p_{h}{ }^{25}$ The quantities $\tilde{x}$ of the remaining $n_{l}$ goods can be freely chosen with corresponding price vector $p$ (from now on, $p$ is an $n_{1}$-vector, without $p_{h}$ ). The constrained quantity $\bar{x}_{h}$ will have spill-over effects on demand for unrationed goods, as shown by the demand functions holding under rationing: ${ }^{26}$

$$
\tilde{x}_{i}=f_{i}\left(m, p, \bar{x}_{h}, p_{h}\right) \quad i=1, \ldots, n_{1}
$$

The equivalent of the Rotterdam specification with rationing can be derived as (where time subscripts $t$ are added):

$$
\begin{gathered}
\tilde{w}_{i t} \Delta \ln \tilde{x}_{i t}=\tilde{a}_{i}+\tilde{b}_{i}\left(\Delta \ln \left(m_{t}-p_{h t} \bar{x}_{h t}\right)-\Sigma_{j} \tilde{w}_{j t} \Delta \ln p_{j t}\right)+\sum_{j} \tilde{s}_{i j} \Delta \ln p_{j t}+\tilde{z}_{i} \Delta \ln \bar{x}_{h t} \\
i, j=1, \ldots, n_{1}
\end{gathered}
$$

where

$$
\begin{aligned}
& \tilde{w}_{i t}=p_{i t} \tilde{x}_{i t} /\left(m_{t}-p_{h t} \bar{x}_{h t}\right) \text { (share in total uncommitted expenditures) } \\
& \tilde{z}_{i}=\text { rationing coefficient with } \Sigma_{i} \tilde{z}_{i}=0
\end{aligned}
$$

Similar theoretical restrictions hold on coefficients $\tilde{a}_{i}, \tilde{b}_{i}, \tilde{s}_{i j}$, and $\tilde{z}_{i}$.

John Neary and K. W. S. Roberts showed the equivalence between demand models with and without rationing by defining virtual prices. ${ }^{27}$ The virtual price $\bar{p}_{h}$ refers to that price that would induce an unrationed consumer to choose exactly the ration level voluntarily, or:

$$
\bar{x}_{h}=f_{h}\left(\bar{m}, p, \bar{p}_{h}\right) \quad \text { and } \quad \tilde{x}_{i}=f_{i}\left(\bar{m}, p, \bar{p}_{h}\right)=\tilde{f}_{i}\left(m, p, \bar{x}_{h}, p_{h}\right) \quad i=1, \ldots, n_{1}
$$

with virtual income $\bar{m}=m+\left(\bar{p}_{h}-p_{h}\right) \bar{x}_{h}$. In other words, a free individual only restricted by virtual income and faced with virtual prices would pur-

\footnotetext{
${ }^{24}$ For a more elaborate discussion, see Neary and Roberts, "Theory," pp. 25-35; and Bettendorf and Barten, "Rationing," pp. 2-4. Neary, "Rationing," pp. 92-96, provides a nontechnical overview.

${ }^{25}$ The framework can easily include quantity constraints for several goods.

${ }^{26}$ Formally, equation 5 is derived from $\max _{\tilde{x}}\left[u\left(\tilde{x}, \bar{x}_{h}\right)\right.$, s.t.p $\left.p^{\prime} \tilde{x}+p_{h} \bar{x}_{h}=m\right]$.

${ }^{27}$ Neary and Roberts, “Theory," pp. 31-35.
} 
chase the observed bundle $\left(\tilde{x}, \bar{x}_{h}\right)$. Or, abolishing the quantity constraint while changing the price to its virtual level would leave the optimal bundle unaffected and all markets would clear when supply is kept constant.

By means of the equalities in equation 7 one can show that the derivatives of rationed demand equations with regard to each of the exogenous variables can be expressed in terms of the derivatives of the corresponding free demand equations when evaluated at virtual prices. ${ }^{28}$ First, for the derivative with regard to the ration level holds that

$$
\partial \tilde{x}_{i}^{c} / \partial \bar{x}_{h}=\left(\partial x_{i}^{c} / \partial p_{h}\right) /\left(\partial x_{h}^{c} / \partial p_{h}\right)
$$

where the superscript $c$ denotes compensated demand. ${ }^{29}$ By the law of demand the denominator is negative such that the sign of $\partial \tilde{x}_{i}^{c} / \partial \bar{x}_{h}$ is the opposite sign of that of $\partial x_{i}^{c} / \partial p_{h}$. When the latter is positive (negative) goods $i$ and $h$ are substitutes (complements) and raising the ration level will de(in)crease good $i$ 's compensated demand.

Second, the effect of a change in nominal income can be decomposed into the normal income effect without rationing and a spill-over effect from rationing: ${ }^{30}$

$$
\partial \tilde{x}_{i} / \partial m=\partial x_{i} / \partial m-\left(\partial \tilde{x}_{i}^{c} / \partial \bar{x}_{h}\right)\left(\partial x_{h} / \partial m\right)
$$

Normally $\partial x_{h} / \partial m>0$ and the sign of the spill-over effect depends on the substitute-complement relationship from equation 8 . Finally, compensated price changes too under rationing have a direct and an indirect effect: ${ }^{31}$

$$
\partial \tilde{x}_{i}^{c} / \partial p_{j}=\partial x_{i}^{c} / \partial p_{i}-\left(\partial \tilde{x}_{i}^{c} / \partial \bar{x}_{h}\right)\left(\partial x_{h}^{c} / \partial p_{j}\right)
$$

The second term reflects that a change in the price of an unrationed good too affects the extent to which a consumer is tied down by the quantity constraint.

These equalities imply that results on unrestricted demand functions can be employed to understand behavior under rationing. Calculation of the virtual price $\bar{p}_{h}$ is an interesting exercise to assess the real extent of the rationing. In the next section estimation of a free (equation 4) and a constrained (equation 6) demand model is combined with equations 8 to 10 to compute the virtual price of rents in interwar Belgium. ${ }^{32}$

\footnotetext{
${ }^{28}$ Appendix 2 gives the expressions of these derivatives for the specific demand equations 4 and 6 .

${ }^{29}$ This is equation 19 of Neary and Roberts, "Theory."

${ }^{30}$ Compare equation 24 of Neary and Roberts, "Theory."

${ }^{31}$ For example, see equation 28 of Neary and Roberts, "Theory."

${ }^{32}$ The models were estimated with the program DEMMOD; see Barten and Geyskens, "Negativity Condition," pp. 227-60. Technical details on the calculation of virtual prices can be found in Bettendorf and Barten, "Rationing." For data, see Table 2 and N.I.S., "Nationale Rekeningen," various issues. The computer program used is available from the authors on request.
} 
TABLE 2

CLASSIFICATION AND BUDGET SHARES (percentage)

\begin{tabular}{llrrrr}
\hline \hline & & & Mean & Mean \\
Variable & \multicolumn{1}{c}{ Description } & 1920 & 1939 & $1920-1939$ & $1953-1993$ \\
\hline FOOD & Food & 45.4 & 31.1 & 36.0 & 22.5 \\
BETO & Beverages and tobacco & 10.7 & 8.3 & 9.8 & 6.7 \\
CLCA & Clothing, footwear, personal & & & & \\
& $\quad$ care, and health & 11.1 & 11.4 & 11.1 & 16.2 \\
RENT & Rent & 5.1 & 14.9 & 10.9 & 9.9 \\
$H E L I$ & Heating and lighting & 5.1 & 6.3 & 5.3 & 5.3 \\
TRCO & Transport and communication & 3.0 & 5.7 & 4.7 & 7.2 \\
WFISE & Entertainment and recreation & 8.8 & 8.5 & 9.9 & 8.7 \\
& Durables and others & 10.8 & 13.8 & 12.3 & 23.5 \\
\hline
\end{tabular}

Source: Schroeven, Consumer Expenditure, pp. 246-49; and Buyst, Inkomen, p. 22.

\section{ESTIMATION RESULTS}

First, the Rotterdam model, equation 6 , is estimated with per capita expenditure data for Belgium from 1920 to $1939 .{ }^{33}$ Control of the housing market was assumed effective for the whole period in order to obtain sufficient observations. A problem of this choice is that years with a strict rent control are combined with years with less binding rationing. In order to check the sensitivity of the outcomes to the last years, experiments with smaller samples were performed. The smallest sample for which the procedure still converged consisted of the period 1920 to 1935. The resulting virtual prices turned out to be fairly robust to the number of observations. ${ }^{34}$ Methods that give smaller weights to years characterized by a less controlled housing market are thought to result in higher virtual prices.

Data on private consumption and spending on housing were classified into 8 aggregates $\left(n_{1}=7\right)$, as described in Table 2 . The relaxing of rent control is clearly mirrored by an almost tripling of the budget share of housing in the sample. The estimated coefficients and standard errors are found in Appendix 1; the implied elasticities evaluated for the mean share are reported in Table 3 . The income elasticities show that all goods were luxury items, except FOOD and $H E L I$, and all demands were rather insensitive to own price changes. Remarkable is that the ration level for $R E N T$ is only significant in the $C L C A$-equation, indicating that a 1 percent increase in the quantity of housing reduces demand for $C L C A$ with 5.6 percent. In this context, it is interesting to point out that Angus Deaton estimated a demand

\footnotetext{
${ }^{33}$ Whereas the theory deals with an individual consumer, this empirical part is applied to aggregated data. We assume that a representative household involves aggregation problems; in particular, the fact that households are affected to a different extent by rent control is ignored. Among others, the type of rationing scheme should be considered in an analysis with heterogenous agents, see Gould and Henry, "Effects," pp. 42-49.

${ }^{34}$ In the smallest sample 1926 becomes an outlier.
} 
TABLE 3

ELASTICITIES RESTRICTED ROTTERDAM MODEL 1920-1939

\begin{tabular}{lccccccc}
\hline \hline Elasticity & FOOD & BETO & CLCA & HELI & TRCO & LEIS & OTHE \\
\hline$\eta_{i}$ & 0.524 & 1.591 & 1.342 & 0.536 & 1.251 & 1.789 & 1.075 \\
$\varepsilon_{i i}^{c}$ & -0.099 & -0.508 & -0.277 & -0.358 & -0.787 & -0.527 & -0.119 \\
$\varepsilon_{i i}$ & -0.310 & -0.683 & -0.445 & -0.390 & -0.854 & -0.726 & -0.268 \\
$\boldsymbol{\gamma}_{i}$ & 1.177 & -0.123 & -5.637 & 2.987 & 2.279 & 0.774 & -1.030 \\
\hline
\end{tabular}

Notes: $\eta_{i}=\tilde{b}_{i} / \tilde{w}_{i}$ (income elasticity)

$\varepsilon_{i i}^{c}=\tilde{s}_{i i} / \tilde{w}_{i}$ (compensated own price elasticity)

$\varepsilon_{i i}=\varepsilon_{i i}^{c}-\eta_{i} \tilde{w}_{i}$ (uncompensated own price elasticity)

$\gamma_{i}=\tilde{z}_{i} / \tilde{w}_{i}$ (elasticity with regard to quantity RENT)

where $\tilde{w}_{i}$ is the mean share in total uncommitted expenditures. The coefficients are taken from Appendix Table 1.

system under rationing with post-World War II British data ${ }^{35} \mathrm{He}$ found that an increase in rationed housing depressed food and clothing expenditure and stimulated spending on transport and communication.

The parameters of equation 4 describing behavior in the absence of rationing are estimated on data for the period 1953 to 1993 (see Appendix Table 2). ${ }^{36}$ Clearly, the allocation of the budget differed between periods (see Table 2), as is also shown by the estimated average elasticities (see Table 4). $H E L I$ now has the highest income elasticity, whereas TRCO has become income inelastic (the negative income coefficient of $R E N T$ is not significant). The own price elasticities remain rather small.

On the admittedly strong assumption that the estimated demand model for the years 1953 to 1993 can be used to represent the behavior of an unrationed consumer in the interwar period, the estimated coefficients of both

TABLE 4

ELASTICITIES UNRESTRICTED ROTTERDAM MODEL 1953-1993

\begin{tabular}{lllllllll}
\hline \hline Elasticity & FOOD & BETO & CLCA & RENT & HELI & TRCO & LEIS & OTHE \\
\hline$\eta_{i}$ & 0.653 & 1.097 & 1.161 & -0.031 & 1.642 & 0.586 & 1.028 & 1.602 \\
$\varepsilon_{i i}^{c}$ & -0.290 & -0.454 & -0.542 & -0.029 & -0.305 & -0.201 & -0.204 & -0.180 \\
$\varepsilon_{u}$ & -0.437 & -0.526 & -0.730 & -0.026 & -0.392 & -0.243 & -0.293 & -0.556 \\
\hline
\end{tabular}

Notes: $\eta_{i}=b_{i} / w_{i}$ (income elasticity)

$\varepsilon_{i i}^{c}=s_{i i} / w_{i}$ (compensated own price elasticity)

$\varepsilon_{i i}=\varepsilon_{i i}^{c}-\eta_{i} W_{i}$ (uncompensated own price elasticity)

where $w_{i}$ is the mean budget share of Table 2, last column. The coefficients are taken from Appendix Table 2 .

\footnotetext{
${ }^{35}$ Deaton, "Theoretical and Empirical Approaches," p. 70.

${ }^{36}$ Between 1945 and 1952 relatively strict rent controls were imposed again in Belgium. Therefore this period is left out of consideration (for more details, see Buyst, Economic History, pp. 233-34).
} 


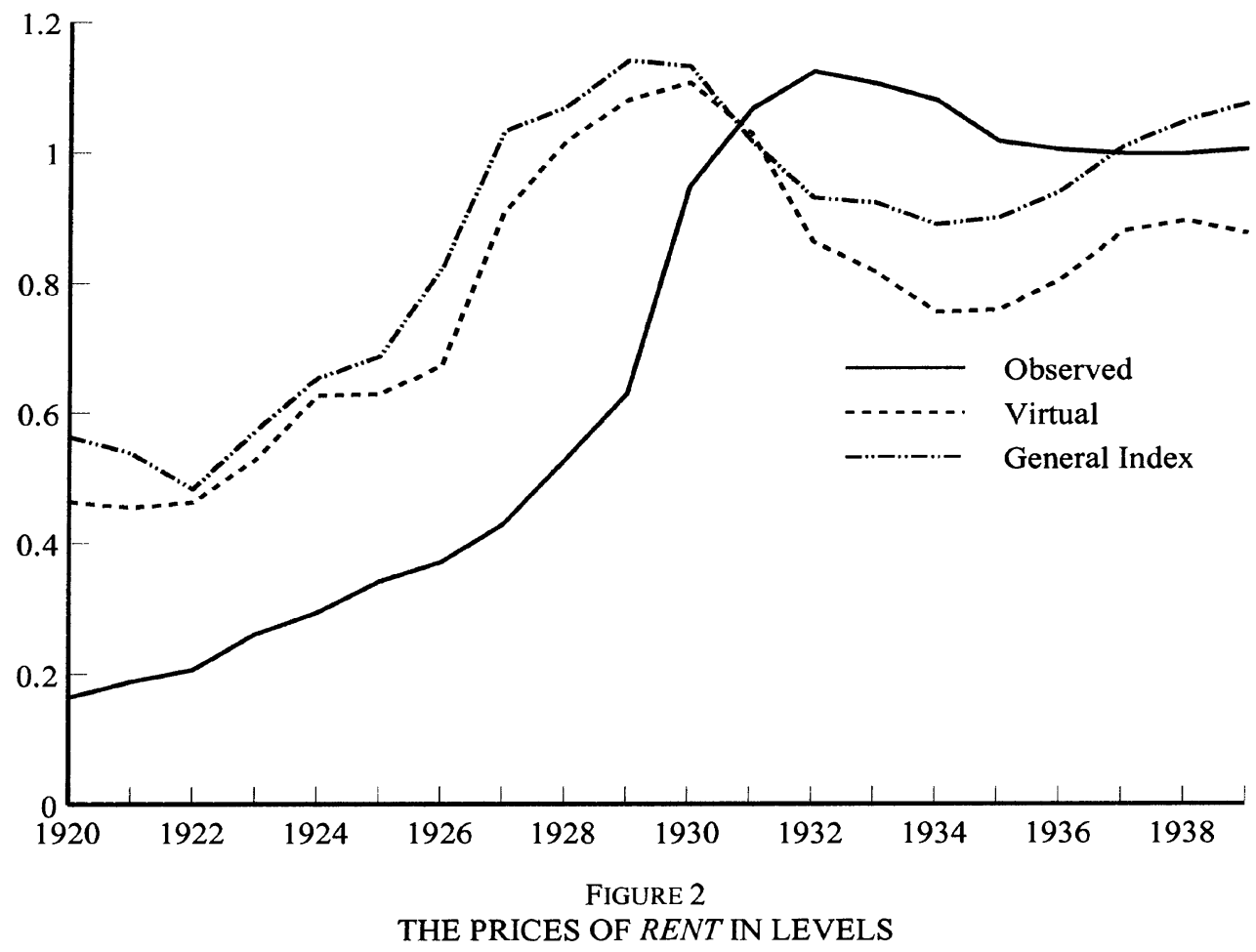

models can be used to evaluate the derivatives in equations 8,9 , and 10 . For each year, these equalities can be considered as a system of equations in one unknown, $\bar{p}_{h}$. The value of $\bar{p}_{h}$ that best fits this system is selected. ${ }^{37}$ As a simple alternative, virtual prices might be calculated by means of a single unrestricted demand equation for housing in the postwar period. However, this method does not make proper use of the analytical relationships nor of the information contained in the observed expenditures on other goods in the prewar and postwar periods. Experiments with this alternative have yielded poor results and the approach based on the two demand models was chosen.

The resulting virtual prices, as given in Figures 2, 3, and 4, are well in line with the description of Section 2 . Figure 2 shows that the level of virtual rent corresponds far better to the general price index (RENT excluded) than to the controlled price. ${ }^{38}$ The monetary crisis of 1926 is reflected in the highest increase in virtual rent in 1927 ( +34.8 percent, Figure 3$)$. While the observed price rose sharply in 1930 (50.5 percent), inflation rates of the virtual and the non-RENT price were already declining. The ratio of virtual to observed rent (solid line in Figure 4) gradually fell from 2.8 in 1920 to

\footnotetext{
${ }^{37}$ The value of $\bar{p}_{h}$ that minimizes the sum of the square of the deviations between the lefthand side and the righthand side of equations 8,9 , and 10 is chosen.

${ }^{38}$ Observed prices are calculated as indices, equal to 1 in $1936-1938$. The general price index (rent excluded $)$ is calculated as $\Sigma_{i} \tilde{w}_{i t} p_{i t} \quad\left(i=1, \ldots, n_{1}\right)$.
} 


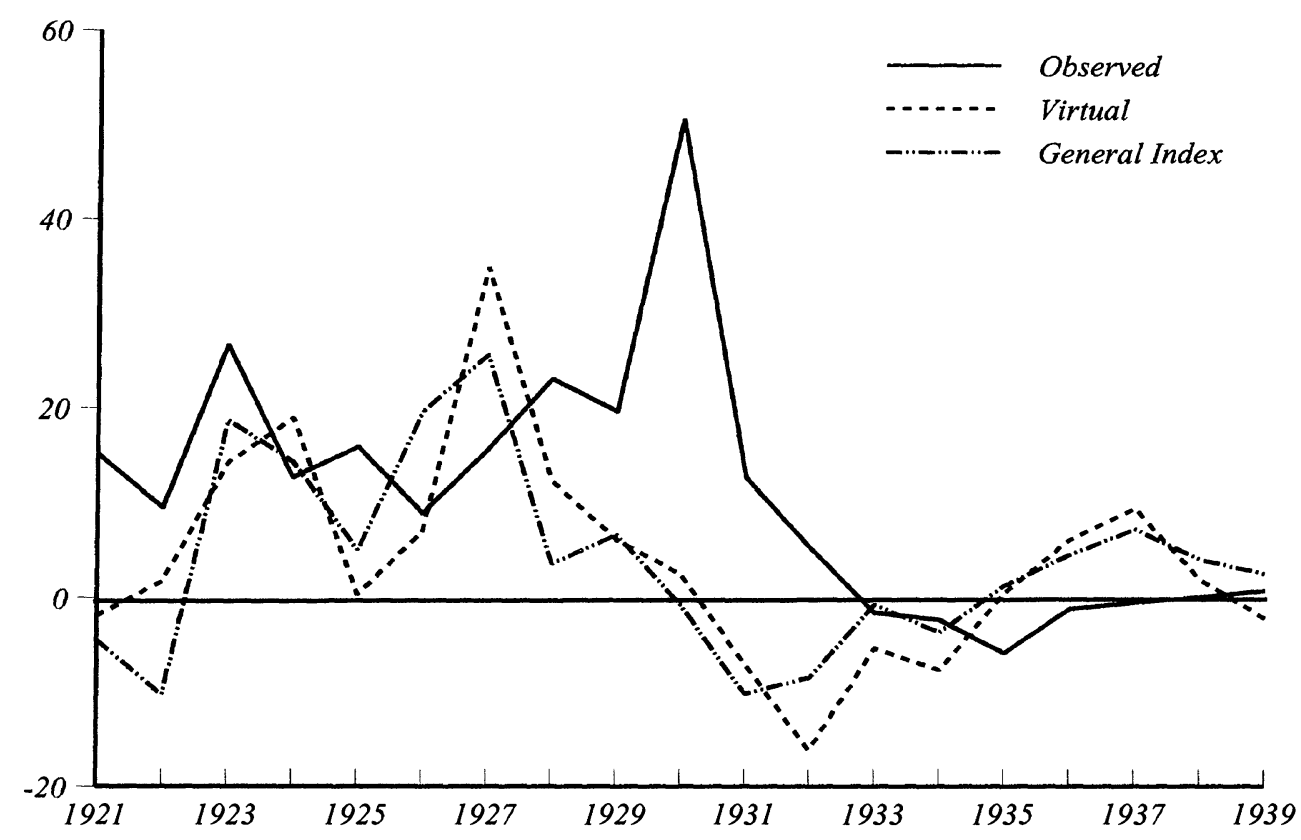

FIGURE 3

THE PRICES OF RENT IN PERCENTAGE CHANGE

0.9 in 1939, illustrating the relaxation of rent-control policies in the late 1920 s. To check the robustness of the results, computations were repeated with the coefficients of Appendix Table 1 and Appendix Table 2, increased and decreased by their standard errors, respectively. Figure 4 shows that the central ratio seems to indicate a lower bound for all years. ${ }^{39}$

\section{THE EFFECTS OF RENT CONTROL ON CONSUMPTION}

The estimated restricted demand model can be used to simulate the effects of alternative rent control policies on consumption. ${ }^{40}$ In a "what-if" scenario, rent price $p_{h}$ is assumed to change at the same rate as the general price index (rents excluded; see Figure 3) till 1931 and is kept at the observed level from 1931 onwards (see Table 5, panel A). The ratio between the hypothetical and the observed rent price always exceeds one and evolves in line with the virtual ratio. Given the observed variables in 1931 , both quantities and

\footnotetext{
${ }^{39}$ Since $\bar{p}_{h}$ is a nonlinear function of the coefficients, the relative position of each of the curves cannot be known a priori. Furthermore, Bettendorf and Barten, "Rationing," pp. 7-8, show that calculations based on the alternative CBS-specification of the demand model does not alter the pattern found for the virtual price.

${ }^{40}$ Pepermans, "De inkomens," pp. 320-22, has performed similar simulations but ignored rationing effects in the estimation. Comparing Pepermans's and our results should be done with care because of the use of different commodity classifications. However, Pepermans also concluded that the budget shares of FOOD and BETO declined the most under constant total real consumption.
} 


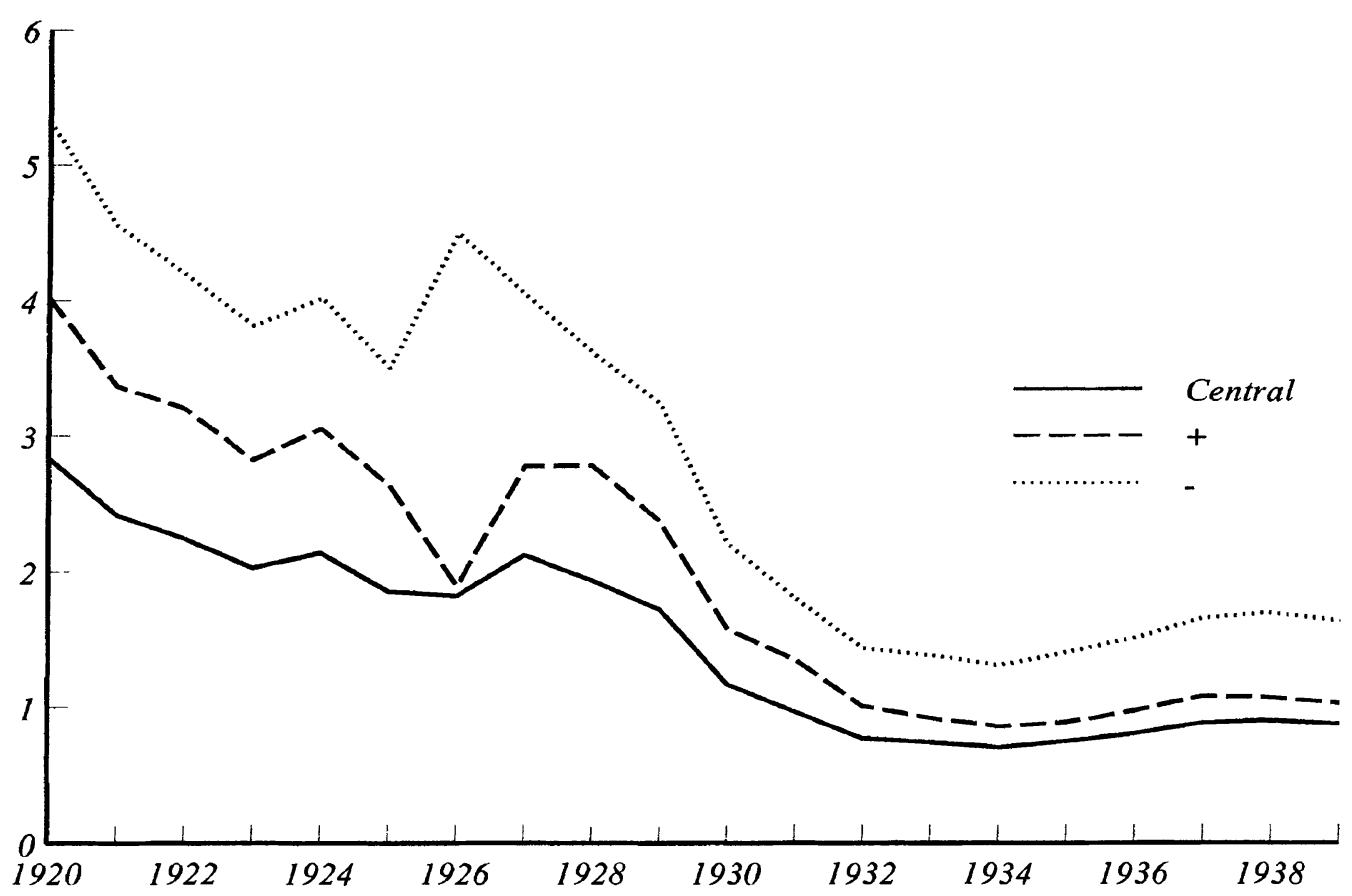

FIGURE 4

THE RATIO VIRTUAL / OBSERVED PRICE RENT

budget shares are calculated backwards from 1930 to 1920 by means of equation 6 . Note that this approach neglects the stimulating effect of higher rents on the quantity of housing supplied. ${ }^{41}$

In a first case, total nominal expenditures $m$ are kept constant at observed values. Holding $m$ and $\bar{x}_{h}$ constant, a higher $p_{h}$ causes a fall in total uncommitted expenditures, ranging from -14 percent to -3 percent. Since only income effects are involved and all unrationed goods have a positive income elasticity, the large increase in the budget share of RENT is compensated by a decrease in all other budget shares, especially of FOOD. As the relative increase in $p_{h}$ gets smaller, the effects on the budget shares diminish.

In a second hypothesis, the total nominal budget is changed to keep real consumption constant after the increase in rents. The necessary rises of $m$, ranging from 10 percent to 2 percent (Table 5, panel $\mathrm{B}$ ), might be thought of as coming from an increase in government transfers, a rise in income or a decrease in savings. The rise in the budget share of RENT is smaller since its denominator $m$ now also increases. All other budget shares decrease, reflecting that the quantitities consumed rise less than the budget. Compared to the first case, the shares of income inelastic goods FOOD and HELI fall by even more since they benefit relatively less from the enlarged budget.

\footnotetext{
${ }^{41}$ The supply of housing is assumed perfectly inelastic whereas the supply of free goods is assumed perfectly elastic.
} 
TABLE 5

SIMULATIONS WITH ALTERNATIVE RENT PRICES

\begin{tabular}{|c|c|c|c|c|c|c|c|c|c|c|}
\hline \multirow[b]{2}{*}{ Year } & \multirow[b]{2}{*}{ Ratio $p_{h}$} & \multirow[b]{2}{*}{ Ratio $\tilde{m}$} & \multicolumn{8}{|c|}{$\begin{array}{l}\text { Change in Budget Shares } \\
\text { (percentage points) }\end{array}$} \\
\hline & & & FOOD & BETO & $C L C A$ & $R E N T$ & $H E L I$ & TRCO & LEIS & OTHE \\
\hline \multicolumn{11}{|c|}{ A. Constant Total Nominal Expenditures } \\
\hline 1920 & 3.62 & 0.86 & -3.3 & -2.4 & -2.3 & 13.2 & -0.4 & -0.6 & -2.4 & -1.9 \\
\hline 1921 & 3.00 & 0.88 & -3.1 & -2.1 & -1.9 & 11.6 & -0.3 & -0.6 & -2.1 & -1.6 \\
\hline 1922 & 2.46 & 0.90 & -2.3 & -1.8 & -1.5 & 9.4 & -0.2 & -0.4 & -1.8 & -1.3 \\
\hline 1923 & 2.30 & 0.90 & -2.4 & -1.6 & -1.4 & 9.0 & -0.2 & -0.4 & -1.7 & -1.2 \\
\hline 1924 & 2.34 & 0.91 & -2.4 & -1.5 & -1.4 & 8.7 & -0.2 & -0.4 & -1.6 & -1.2 \\
\hline 1925 & 2.12 & 0.91 & -2.3 & -1.4 & -1.2 & 8.2 & -0.2 & -0.4 & -1.5 & -1.1 \\
\hline 1926 & 2.33 & 0.90 & -2.4 & -1.5 & -1.4 & 8.9 & -0.3 & -0.4 & -1.7 & -1.2 \\
\hline 1927 & 2.53 & 0.90 & -2.4 & -1.6 & -1.6 & 9.8 & -0.3 & -0.6 & -1.9 & -1.3 \\
\hline 1928 & 2.13 & 0.91 & -1.9 & -1.4 & -1.5 & 8.2 & -0.3 & -0.5 & -1.6 & -1.2 \\
\hline 1929 & 1.90 & 0.92 & -1.7 & -1.2 & -1.2 & 7.2 & -0.2 & -0.5 & -1.4 & -1.1 \\
\hline 1930 & 1.25 & 0.97 & -0.6 & -0.5 & -0.5 & 2.9 & -0.1 & -0.2 & -0.6 & -0.4 \\
\hline \multicolumn{11}{|c|}{ B. Constant Total Real Expenditures } \\
\hline & & Ratio $m$ & & & & & & & & \\
\hline 1920 & & 1.10 & -4.8 & -1.5 & -1.5 & 11.6 & -0.5 & -0.4 & -1.4 & -1.4 \\
\hline 1921 & & 1.09 & -4.2 & -1.3 & -1.3 & 10.2 & -0.5 & -0.4 & -1.2 & -1.2 \\
\hline 1922 & & 1.08 & -3.2 & -1.2 & -1.0 & 8.3 & -0.4 & -0.4 & -1.1 & -1.0 \\
\hline 1923 & & 1.07 & -3.3 & -1.0 & -1.0 & 7.9 & -0.4 & -0.3 & -1.0 & -1.0 \\
\hline 1924 & & 1.08 & -3.2 & -0.9 & -0.9 & 7.7 & -0.4 & -0.3 & -0.9 & -0.9 \\
\hline 1925 & & 1.07 & -3.0 & -0.9 & -0.8 & 7.2 & -0.4 & -0.3 & -0.9 & -0.9 \\
\hline 1926 & & 1.08 & -3.3 & -0.9 & -0.9 & 7.8 & -0.4 & -0.4 & -1.0 & -0.9 \\
\hline 1927 & & 1.08 & -3.4 & -1.0 & -1.1 & 8.6 & -0.5 & -0.4 & -1.1 & -1.1 \\
\hline 1928 & & 1.07 & -2.7 & -0.8 & -1.0 & 7.2 & -0.4 & -0.4 & -0.9 & -1.0 \\
\hline 1929 & & 1.06 & -2.3 & -0.8 & -0.8 & 6.3 & -0.3 & -0.4 & -0.8 & -0.9 \\
\hline 1930 & & 1.02 & -0.8 & -0.4 & -0.4 & 2.6 & -0.1 & -0.2 & -0.4 & -0.4 \\
\hline
\end{tabular}

The reverse holds for income elastic goods.

These simulations show that the observed rent policies especially favored food consumption. These results are illustrated by historical evidence. In the early 1930s Belgian miners complained bitterly that the sharply rising budget share of rents forced them to cut back drastically on food expenditure. ${ }^{42}$ Of course, this was due not only to the effects of rent decontrol but also to the sharp increase in (temporary) unemployment and thus reduced income.

\section{CONCLUSION}

As in other western European countries, the Belgian housing market had rent controls in the 1920s. The large difference between the time path of rents and the general price level (rents excluded) together with the steep rise in rents after the liberalization of the housing market around 1930 suggest

\footnotetext{
${ }^{42}$ Driesen, “Zomerstakingen,” p. 147.
} 
that rent restrictions in Belgium were very severe. Using a Rotterdam demand model, virtual rents were calculated. The ratio of virtual to observed rents reached 2.8 in 1920 and fluctuated around 2 in the period from 1923 to 1929 . These figures not only confirm that Belgian rent control was extremely tight in the 1920s but also give a clearer picture of its trend over time.

A counterfactual exercise assuming that rents in the 1920s followed the general price index (rents excluded) instead of their actual course shows that the effects of rent restrictions on consumption were substantial. Assuming total nominal expenditure constant, the budget share of rents in 1920 would have been 13 percentage points higher than observed. The difference declined in the early 1920 s but still remained around 9 percentage points in the period from 1922 to 1928 . The budget shares of all other spending categories benefitted from rent control, especially the consumption of food. By accident, liberalization of the Belgian housing market coincided with the outbreak of the Great Depression. At the same time that income came under severe downward pressure, rents rose substantially. As a result, the budget share of rents increased dramatically, thereby crowding out spending on all other items. 


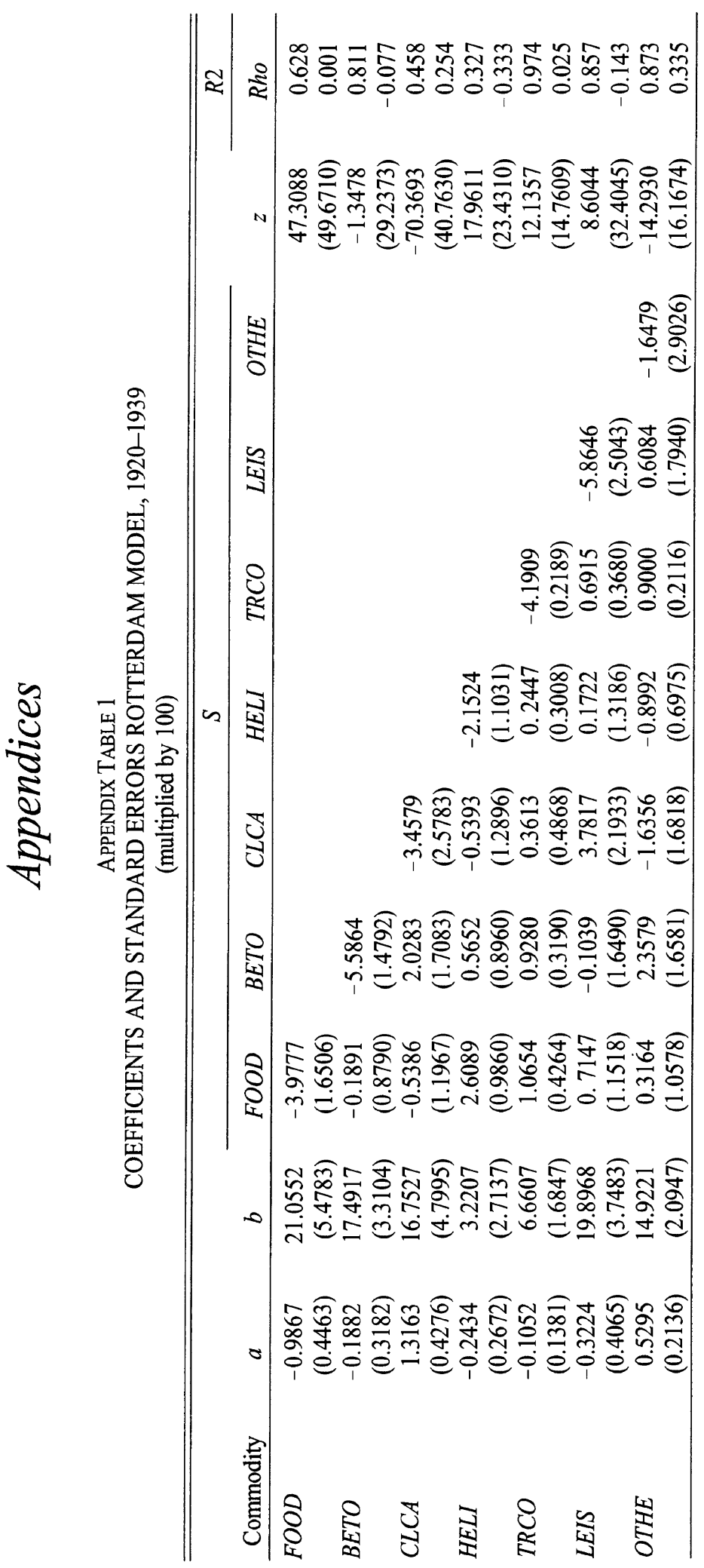




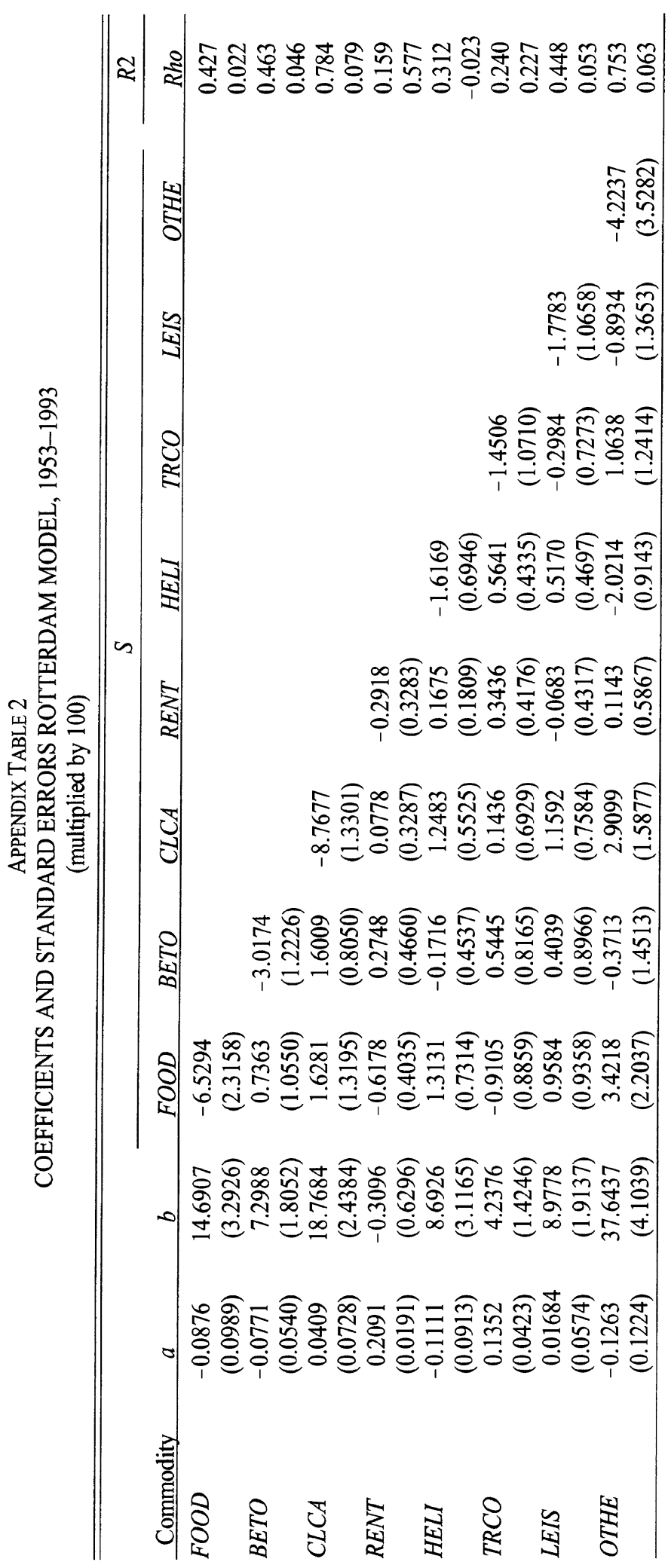


APPENDIX 2: EQUATIONS 8, 9, AND 10

The derivatives of the restricted and unrestricted demand equations can be expressed in terms of the coefficients as follows (the latter are evaluated at the virtual variables): ${ }^{43}$

$$
\frac{\partial \tilde{x}_{i}^{c}}{\partial \bar{x}_{h}}=\frac{\tilde{z}_{i} \tilde{m}-\tilde{b}_{i} p_{h} \bar{x}_{h}}{p_{i} \bar{x}_{h}}
$$

(with $\tilde{m}=m-p_{h} \bar{x}_{h}=$ total uncommitted expenditures)

$$
\begin{array}{ccc}
\frac{\partial x_{i}^{c}}{\partial p_{h}}=\frac{s_{i h} \bar{m}}{p_{i} \bar{p}_{h}} & \frac{\partial x_{h}^{c}}{\partial p_{h}}=\frac{s_{h h} \bar{m}}{\bar{p}_{h}^{2}} \\
\frac{\partial \tilde{x}_{i}}{\partial m}=\frac{\tilde{b}_{i}}{p_{i}} & \frac{\partial x_{i}}{\partial m}=\frac{b_{i}}{p_{i}} & \frac{\partial x_{h}}{\partial m}=\frac{b_{i}}{\bar{p}_{h}} \\
\frac{\partial \tilde{x}_{i}^{c}}{\partial p_{j}}=\frac{\tilde{s}_{i j} \tilde{m}}{p_{i} p_{j}} & \frac{\partial x_{i}^{c}}{\partial p_{j}}=\frac{s_{i j} \bar{m}}{p_{i} p_{j}} & \frac{\partial x_{h}^{c}}{\partial p_{j}}=\frac{s_{h j} \bar{m}}{\bar{p}_{h} p_{j}}
\end{array}
$$

${ }^{43}$ See Bettendorf and Barten, "Rationing," pp. 3-4.

REFERENCES

Arnott, Richard. "Time for Revisionism on Rent Control?" Journal of Economic Perspectives 9 (1995): 99-120.

Banque Nationale de Belgique. Statistiques économiques belges, 1919-1928: Brussels, 1929.

Barten, Anton P. “Consumer Allocation Models: Choice of Functional Form.” Empirical Economics 18 (1993): 129-58.

Barten, Anton P., and Erik Geyskens. "The Negativity Condition in Consumer Demand." European Economic Review 6 (1975): 227-60.

Baudhuin, Fernand. Histoire économique de la Belgique, 1914-1939. 2 vols. Brussels: Bruylant, 1946.

Belgisch Staatsblad [Belgian Law Gazette], various issues.

Bettendorf, Leon, and Anton P. Barten. "Rationing in Demand Systems: Calculation of Virtual Prices." Tinbergen Institute, Discussion Paper TI95-76, Rotterdam, 1995.

Buyst, Erik. An Economic History of Residential Building in Belgium between 1890 and 1961. Studies in Belgian Economic History, Vol. 1. Brussels: Koninklijke Academie voor Wetenschappen, Letteren en Schone Kunsten van België, 1992.

."Het inkomen uit onroerend vermogen toevloeiend aan particulieren: België, 1920-1939 [Income from real estate credited to individuals: Belgium, 1920-1939]." Workshop in Quantitative Economic History, Research Paper 94.01, Leuven, 1994.

Buyst, Erik et al. "National Accounts for the Low Countries: The Netherlands and Belgium, 1800-1990." Scandinavian Economic History Review 43 (1995): 53-76.

Cassiers, Isabelle. Croissance, crise et régulation en économie ouverte. La Belgique entre les deux guerres. Brussels: De Boeck, 1989.

Deaton, Angus. "Theoretical and Empirical Approaches to Consumer Demand Under Rationing." In Essays in the Theory and Measurement of Consumer Behaviour, edited by Angus Deaton, 55-72. Cambridge: Cambridge University Press, 1981. 
Deaton, Angus, and John Muellbauer. Economics and Consumer Behavior. Cambridge: Cambridge University Press, 1980.

Driesen, Frans. "De zomerstakingen van 1932 in Henegouwen [The Strikes in the Summer of 1932 in the Province of Hainaut]." In Studia Historica Oeconomica: Liber Alumnorum Herman Van der Wee, edited by Erik Aerts et al., 145-59. Leuven: Leuven University Press, 1993.

Gobyn, Ronny. "De woningnood en het probleem van de voorlopige huisvesting in België na de Eerste Wereldoorlog [The housing shortage and the problem of temporary housing in Belgium after the First World War]." In Resurgam: De Belgische wederopbouw na 1914, edited by Marcel Smets, 169-87. Brussels: Gemeentekrediet van België, 1985.

Gould, J., and S. Henry. "The Effects of Price Control on a Related Market." Economica 34 (1967): 42-49.

Henau, Anne. "De Belgische huishuren gedurende het interbellum [Rents in interwar Belgium]." Workshop in Quantitative Economic History, Discussion Paper 91.01, Leuven, 1991.

Hogg, Robin L. Structural Rigidities and Policy Inertia in Inter-war Belgium. Klasse der Letteren, Vol. 118. Brussels: Koninklijke Academie voor Wetenschappen, Letteren en Schone Kunsten van België, 1986.

Kurz, Daniel. "Den Arbeiter zum Bürger machen - Gemeinnütziger Wohnungsbau in der Schweiz 1918-1949." In Wohnungspolitik im Sozialstaat. Deutsche und europäische Lösungen 1918-1960, edited by Günther Schultz, 285-304. Düsseldorf: Droste, 1993.

Leeman, August. De woningmarkt in België (1890-1950) [The housing market in Belgium (1890-1950)]. Reeks van de School voor Economische Wetenschappen, Vol. 50. Kortrijk: Vermaut, 1955.

Lescure, Michel. Immobilier et bâtiment en France (1820-1980). Paris, 1983.

Mommen, André. The Belgian Economy in the Twentieth Century. London: Routledge, 1994.

Neary, John P. "Rationing." In The New Palgrave. A Dictionnary of Economics, edited by John Eatwell et al., 92-96. London: Macmillan, 1987.

Neary, John P., and K. W. S. Roberts. "The Theory of Household Behaviour Under Rationing." European Economic Review 13 (1980): 25-42.

N.I.S. "De nationale rekeningen van België [National accounts of Belgium]." Statistische Studiën, various issues.

Pepermans, Guido. "De inkomens- en prijsgevoeligheid van de Belgische private consumptie in het interbellum [Income and price elasticities of Belgian private consumption in the interwar period]." In Studia Historica Oeconomica: Liber Alumnorum Herman Van der Wee, edited by Erik Aerts et al., 311-24. Leuven: Leuven University Press, 1993.

Phlips, Louis. Applied Consumption Analysis. Amsterdam: North-Holland, 1990.

Pooley, Colin G., ed. Housing Strategies in Europe, 1880-1930. Leicester: Leicester University Press, 1992.

Richardson, Harry, W., and Derek H. Aldcroft. Building in the British Economy Between the Wars. London: George Allen and Unwin, 1968.

Schepens, Luc. "België in de Eerste Wereldoorlog [Belgium in the First World War]." In Algemene Geschiedenis der Nederlanden, Vol. 14, edited by D. P. Blok, 19-39. Haarlem: Fibula-Van Dishoeck, 1979.

Schokkaert, Erik, and Herman Van der Wee. "A Quantitative Study of Food Consumption in the Low Countries during the Sixteenth Century." The Journal of European Economic Historv 17 (1988): 131-58. 
Schroeven, Chris. Consumer Expenditure in Interwar Belgium: The Reconstruction of a Database. Studies in Belgian Economic History, Vol. 4. Brussels: Koninklijke Academie voor Wetenschappen, Letteren en Schone Kunsten van België, 1994.

Strömberg, Thord. "Sweden." In Housing Strategies in Europe, 1880-1930, edited by Colin G. Pooley, 11-39. Leicester: Leicester University Press, 1992.

Thomas, R. L. Applied Demand Analysis. London: Longman, 1987.

Van den Eeckhout, Patricia. "Belgium." In Housing Strategies in Europe, 1880-1930, edited by Colin G. Pooley, 190-220. Leicester: Leicester University Press, 1992.

Van der Wee, Herman, and Karel Tavernier. La Banque Nationale de Belgique et l'histoire monétaire entre les deux guerres mondiales. Brussels: Banque Nationale de Belgique, 1975.

Varian, Hal R. Microeconomic Analysis. New York: Norton, 1992. 
http://www.jstor.org

\title{
LINKED CITATIONS
}

\author{
- Page 1 of 2 -
}

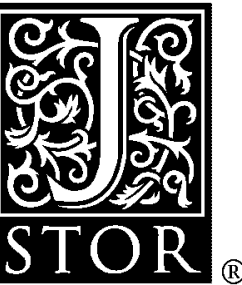

You have printed the following article:

Rent Control and Virtual Prices: A Case Study for Interwar Belgium

Leon Bettendorf; Erik Buyst

The Journal of Economic History, Vol. 57, No. 3. (Sep., 1997), pp. 654-673.

Stable URL:

http://links.jstor.org/sici?sici=0022-0507\%28199709\%2957\%3A3\%3C654\%3ARCAVPA\%3E2.0.CO\%3B2-N

This article references the following linked citations. If you are trying to access articles from an off-campus location, you may be required to first logon via your library web site to access JSTOR. Please visit your library's website or contact a librarian to learn about options for remote access to JSTOR.

\section{[Footnotes]}

\author{
${ }^{5}$ Time for Revisionism on Rent Control? \\ Richard Arnott \\ The Journal of Economic Perspectives, Vol. 9, No. 1. (Winter, 1995), pp. 99-120. \\ Stable URL: \\ http://links.jstor.org/sici?sici=0895-3309\%28199524\%299\%3A1\%3C99\%3ATFRORC\%3E2.0.CO\%3B2-W \\ ${ }^{33}$ The Effects of Price Control on a Related Market \\ J. R. Gould; S. G. B. Henry \\ Economica, New Series, Vol. 34, No. 133. (Feb., 1967), pp. 42-49. \\ Stable URL: \\ http://links.jstor.org/sici?sici=0013-0427\%28196702\%292\%3A34\%3A133\%3C42\%3ATEOPCO\%3E2.0.CO\%3B2-K
}

\section{References}

\section{Time for Revisionism on Rent Control?}

Richard Arnott

The Journal of Economic Perspectives, Vol. 9, No. 1. (Winter, 1995), pp. 99-120.

Stable URL:

http://links.jstor.org/sici?sici=0895-3309\%28199524\%299\%3A1\%3C99\%3ATFRORC\%3E2.0.CO\%3B2-W

NOTE: The reference numbering from the original has been maintained in this citation list. 
http://www.jstor.org

\section{LINKED CITATIONS \\ - Page 2 of 2 -}

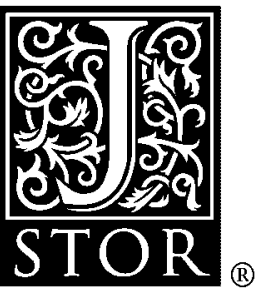

The Effects of Price Control on a Related Market

J. R. Gould; S. G. B. Henry

Economica, New Series, Vol. 34, No. 133. (Feb., 1967), pp. 42-49.

Stable URL:

http://links.jstor.org/sici?sici=0013-0427\%28196702\%292\%3A34\%3A133\%3C42\%3ATEOPCO\%3E2.0.CO\%3B2-K

NOTE: The reference numbering from the original has been maintained in this citation list. 